
A C T A
I C H T H Y O L O G I C A
$\mathbf{E} \mathbf{T}$
P I S C A T O R I A
Vo!. XIX, Fasc. 2
Szczecin 1989

Stawomir WIELGOSZ

Fișh biology

\title{
FACTORS DETERMINING THE FISH COEXISTENCE AND THE ICHTHYOCENOTIC TROPHIC RELATIONS IN WLOCLAWEK DAM RESERVOIR, POLAND
}

\section{CZYNNIKI OKREŚLAJĄCE WSPÓE BYTOWANIE I ZALEŻNOŚCI TROFICZNE W ICHTIOCENOZIE ZBIORNIKA ZAPOROWEGO WE WLOCEAWSKU}

\author{
Chair of Zoology Academy of Agriculture and Technology \\ in Olsztyn
}

\begin{abstract}
In the work feeding interrelations of the main fishes feeding on benthos, in Wrockawek dam reservoir, was estimated and the fishes growth rate and condition was compared. A block diagram of the trophic web, for the most numerous fish species, such as: (Abramis brama (L.), Rutilus rutilus (L.), Blica björkna (L.), Stizostedionlucioperca (L.), Perca fluviatilis (L.), Gymnocephalus cernus (L.), Gobio gobio (L.) was estimated.

Material for analysis was collected from 1982 to 1984, between April and October, every two weeks (1982), every month 1984 and with seasonal intervals (1983) in the lowland dam reservoir at the Vistula River around Whockawek.
\end{abstract}

\section{INTRODUCTION}

Food relations between the coexisting fish species are determined by partitioning of the environment resources (Stolarov 1985; Langhlin and Werner 1980, Lammens 1984, Abel-Malek 1980, Vijverberg and van Densen 1984). Hence, the degree into which the mutritional requirement of the fish are being covered depends on the resource availability 
and abundance. Diets of the allopatric species become similar only in the periods when the food resources are fairly abundant.(Brabrand 1984, Perison et al. 1985, Mittelbach 1984 ) and then the fish codnition is usually good (Lammens et al. 1985 a). Contrary to this, niches of the predators usually shirt in the periods of low resource abundance, this being a symptom of the interspecific competition. Its causes are: a decrease of the resource abundance, or of the preferred prey. Niche shirts may be either temporary (for instance in the periods of fauna emergence) or permanent (for instance, due to an introduction of the fishes which mediate consumption of the local species Anderson et al. 1978, Lynch 1979, Crowder and Cooper 1982).

Studies on the interaction in and between the fish species, fish diet, and potential resources of the environment can be used in predicting dynamic changes in the ichthyocenoses. They can also be of use in the decision-making process as to possible intervention in the ecosystem aimed at better utilization of the available food resources (Zheltenkova and Kogan 1985). This is done by an anhancement of the stocks of more valuable fishes which, at the same time, are more efficient as regards the transfer of matter and energy in the system.

This paper presents data on the rate of growth and fish condition in Włocławek Dam Reservoir as well as on the food relations of the main benthivorous fishes.

\section{MATERIAL AND METHODS}

The materials were the fishes dominating in the reservoir. Fish catches were performed in 1982-1984 with gill nets (mesh size 35-70 mm) and a seine (mesh size $30 \mathrm{~mm}$, wing length $150 \mathrm{~m}$ ). In 1982 and 1984, catches were made since Aprill till October at two-week (1982) or monthly (1984) intervals. In 1983, catches were made seasonally (April, July, October). All the fishes were weighed and measured (Lt and Lc), an teir sex was determined.

In analysing the trophic relations advantage was taken of the specialistic reviews on bream (Abramic brama), white bream (Blicca björkna), pike-perch (Stizostedion lucioperca), roach (Rutilus rutilus), perch (Perca fluviatilis), ruff (Gymnocephalus cernua) and gudgeon (Gobio gobio). Detalis of the methods used in analysing the fish diet can be found in Terlecki 1987, Szczyglińska 1987, Boroń and Kuklińska 1987, and Wielgosz and Tadajewska 1988.

Food selectivity was determined using the efficiency index (E) of Ivlev (1955): $E=r_{1}-p_{1}\left(r_{1}+p_{1}\right)$, where $r_{1}-$ share of the given component in total food weight, $p_{1}-$ share of the given component in total biomass of the environmental resources. Feeding efficiency of the benthivorous fishes was calculated multiplying the amount of the consumed chironomids by g0.8 (Lammens et al. 1985 a). Similarity of the fish diets was estimated from Shorygin's index (1939). Condition of the fishes was determined for each cohort (Lc) using Fulton's parameter $\mathrm{F}=\mathrm{W} / \mathrm{L}^{3} \times 100$, where $\mathrm{W}$ - fish weight in $\mathrm{g}, \mathrm{L}-$ body length in $\mathrm{cm}$ (Ricker 1975). The fishes were grouped into comparable cohorts of 
$5 \mathrm{~cm} \mathrm{Lc}$ interphase. Roach and perch were divided into three cohorts (I-IIIr and I-IIIp) embracing the length range from 10.0 to $25.0 \mathrm{~cm}$. Bream and white bream were grouped into five cohorts ( $\mathbb{I}-\mathrm{Vb}$ and $\mathbb{I}-\mathrm{Vwb}$ ) from 10.0 to $3.0 .1 \mathrm{~cm}$, while ruff and gudgeaon into two size-classes (I-IIrf and I-IIg) of belowe and over $5 \mathrm{~cm} \mathrm{Lc}$. Hence, it was possible to compare the condition of various species in the same size-classes. Pike-perch was analysed as a whole due to the fact its diet did not differ dependaing on the fish size. Significance of the differences was determined using Student's test $t$.

\section{RESULTS AND DISCUSSION}

\section{Potential resources of the environment}

Average densities of the zooplankton in 1980-1982 amolinted to 960, 790 and 300 indiv. $\mathrm{dm}^{-3}$ respectively. A decrease of the flushing rate in 1983 and 1984 resulted in an

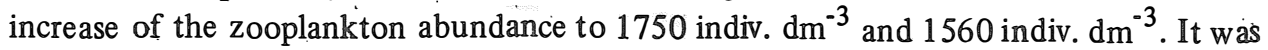
found that plankton density was inversely proportional to the flow rate noth in the lotic and lenitic zone of the reservoir. As regards the vertical profile, the nearbottom zone was about 1.3 to 2.6 times more fertile than other water layers. Rotatoria were most numerous (Fig. 1). However on the rotifers depended on thickness of the filtrating apparatus of the planktivorous fishes and on the size-specific selectivity. Copepoda and Cladocera were distributed irregularly but were readily consumed by the fishes. Drastic

Table|1

Density (individuals. $\mathrm{m}^{-2}$ ) and biomas $\left(\mathrm{g} \mathrm{m}^{-2}\right.$ ) of the benthos in 1982 and 1984. Based on data by Giżyński (1983) and Ciumelis (1985)

\begin{tabular}{|c|rr|rr|rr|rr|}
\hline \multirow{2}{*}{ Year } & \multicolumn{2}{|c|}{ Chironomidae } & \multicolumn{2}{|c|}{ Oligochaeta } & \multicolumn{2}{|c|}{ Mollusca } & \multicolumn{2}{|c|}{ Total zoobenthos } \\
\cline { 2 - 9 } Month & ind.m $^{-2}$ & $\mathrm{~g} \mathrm{~m}^{-2}$ & ind. $\mathrm{m}^{-2}$ & $\mathrm{~g} \mathrm{~m}^{-2}$ & ind. $\mathrm{m}^{-2}$ & $\mathrm{~g} \mathrm{~m}^{-2}$ & ind. $^{-2}$ & $\mathrm{~g} \mathrm{~m}^{-2}$ \\
\hline 1982 & & & & & & & & \\
05 & 74 & 0.37 & 715 & 3.83 & 8 & 3.68 & 796 & 7.89 \\
06 & 1302 & 11.29 & 2008 & 12.81 & 141 & 70.67 & 3456 & 94.85 \\
09 & 279 & 0.79 & 392 & 0.61 & 0 & 0 & 671 & 1.39 \\
11 & 272 & 1.74 & 2563 & 8.08 & 0 & 0 & 2835 & 9.82 \\
1984 & & & & & & & & \\
05 & 39 & 0.06 & 6500 & 22.60 & 134 & 4.92 & 6673 & 27.58 \\
07 & 567 & 6.58 & 5379 & 20.34 & 1119 & 702.32 & 7099 & 729.52 \\
08 & 2292 & 27.88 & 7095 & 18.54 & 321 & 164.02 & 9814 & 210.41 \\
11 & 778 & 15.86 & 13818 & 30.79 & 668 & 340.75 & 15847 & .388 .19 \\
\hline
\end{tabular}




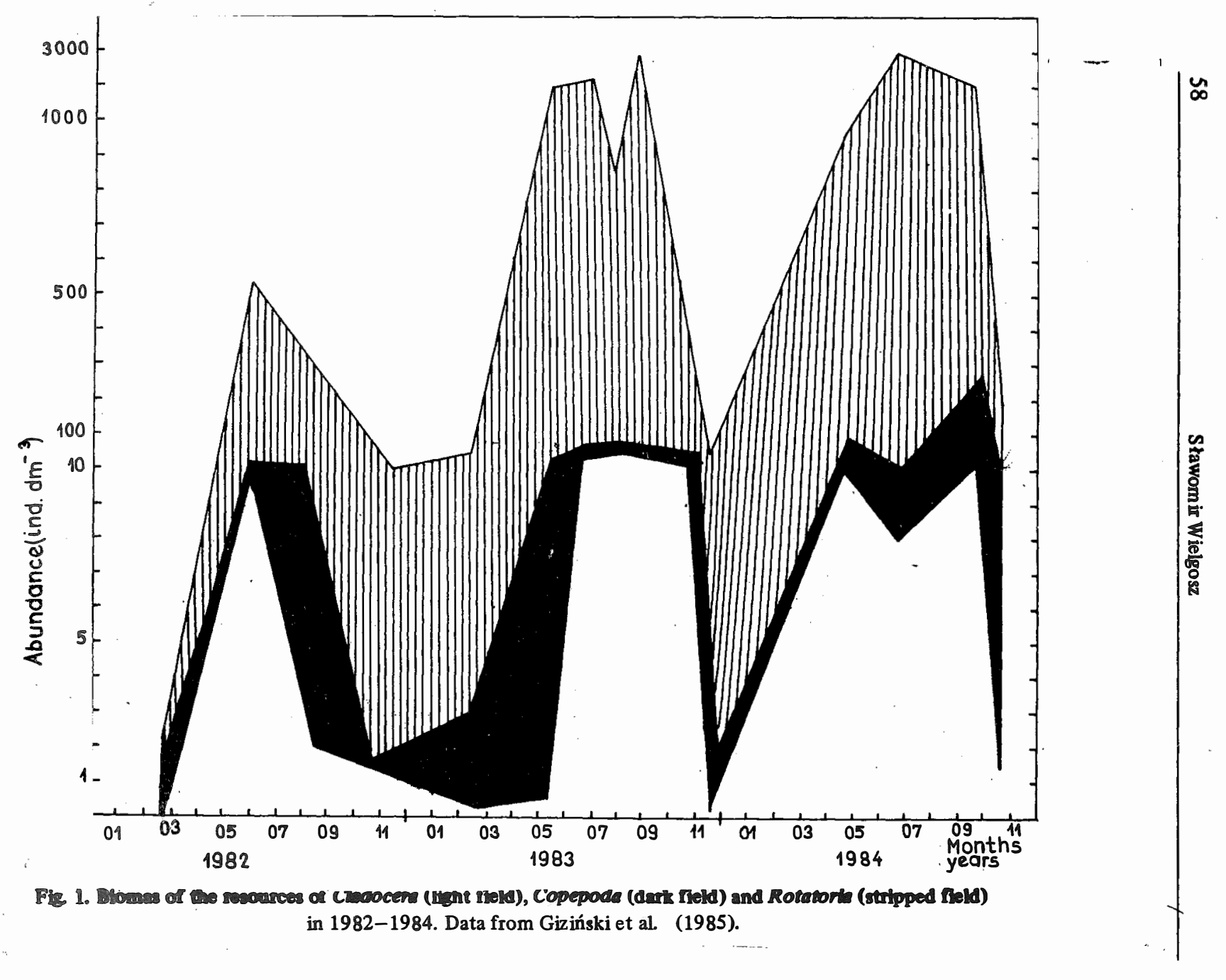


Classification of the feeding behaviour of fish from particular cohorts in Włocławek Reservoir.

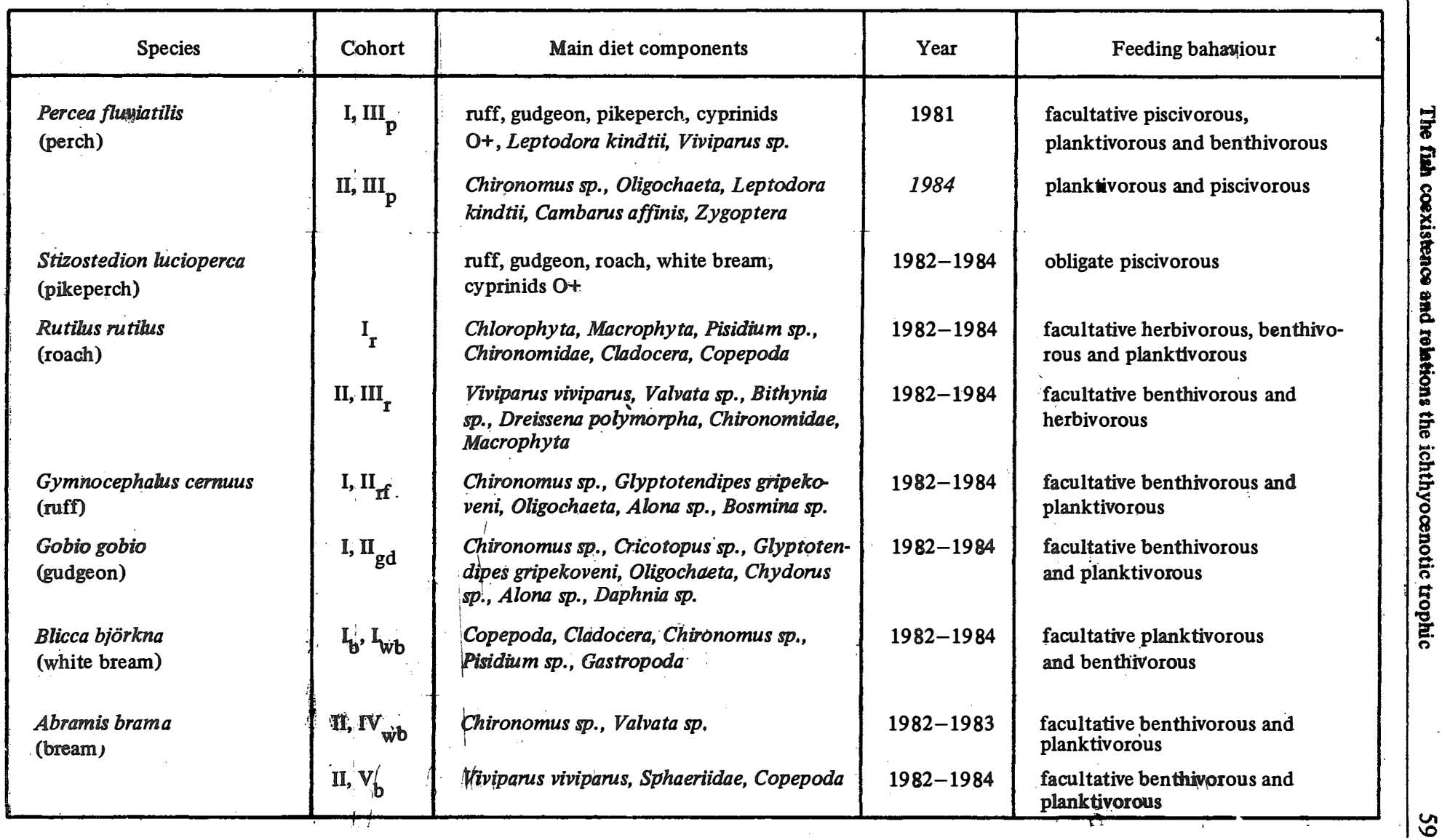


variations in the biomass of the pelagic zooplankton (from $0.003 \mathrm{~g} \mathrm{~d} . w \hat{t} . \mathrm{dm}^{-3}$ to $5 \mathrm{~g}$ dry weight $\mathrm{dm}^{-3}$ ) were determined by the hydrobiological regime induced by the power plant (Giziński et al., 1985). Stability and abundance of the bottom resources also depended on the flow rate which resulted in re-suspension, transfer and re-sedimentation of the sediments. Oligochaeta and Chironomidae were the most important components of the bottom resources. Agregations of Mollusca (Dreissena polymorpha and Sphaeriidae most of all) were found only in a few places and then biomass of the bottom fauna reached a few hundred $\mathrm{g}$ fresh weight $\mathrm{m}^{-2}$ (Tab. 1). Biomass of soft zoobenthos increased with time,

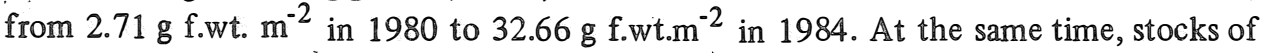
Chironomus spp., Glyptotendipes gripekoveni and Limnodrillus sp. became predominated by large forms (Giżynski 1983, Ciunelis 1985). This favoured their effective utilization by the fishes.

Stock of small-sized fishes was predominated by bleak, ruff and gudgeon, followed by juvenile bream, perch, roach and pike-perch, less frequently white bream, dace and Vimba. Densisties of these fishes ranged from 0.21 to 3.05 indiv. $\mathrm{m}^{-2}$. $\mathrm{yr}^{-1}$ in 1983 , and from 0.49 to 6.31 indiv. $\mathrm{m}^{-2} \cdot \mathrm{yr}^{-1}$ in 1984 , although no regular variation were observed. Totally, about $70 \%$ of total fish numbers were represented by non-exploited fishes. Bleak penetrated surface waters, while ruff and gudgeon were present down to $5 \mathrm{~m}$ depth (Grudniewski 1985).

\section{Structural inter-relations in the fish diet}

Differences in the fish diet were observed between the species and size-classes. They were determined by prey availability in the phenological cycle and in different years.

Juveniles of roach, bream and white bream fed mostly on various size-fractions of the zooplankton and on.plants (Tab. 2). Predatory and non-predatory chironomids were consumed mostly by bream Ib and white bream Iwb. On the other hand, diet of ruff and gudgeon was similar to that of adult bream and white bream. Some differences were noted only as regards the quantitative levels of prey selected from the available bottom resources. A decreasing trend of Cladocera and Copepoda levels in the diet was coupled with an increase of Chironomidae, Oligochaeta and Mollusca which took place as the fish grew. Frequency of the chironomids in gudgeon diet amounted to about $88.1 \%$ and in ruff diet to about $94.9 \%$ (Tab. 3). Size of the ingested larvae correlated with the fish size (Boron and Kuklińska 1987). However, it was notet that gudgeon preffered small, phytophilic froms of Crocotopus, while ruff consumed bigger, ubiquitic specimens of Glyptotendipes gripekovani and pelophilic Chironomus spp.

A drastic "change of the diet was observed for pech and pilkeperch stocks. This change was caused by a change in the prey availability. In 1981, perch was a typical facultative predator (60-90\% of the food weight). In 1984, invertebrates constituted over $80 \%$ of its diet despite the fact that the potential fish fry resources were fairly abundant. Pike-perch was an obligatory predator (Tab. 2). It fed mostly on ruff in spring and on gudgeon and ruff in summer and autumn (Terlecki 1987). Adult pike-perch consumed also bream and 
Table 3

Frequency of main components in the fish diet (in \%)

\begin{tabular}{|l|c|c|c|c|c|c|c|}
\hline \multicolumn{1}{|c|}{ Diet components } & Roach & Perch & Gudgeon & Ruff & $\begin{array}{c}\text { White } \\
\text { bream }\end{array}$ & Bream & $\begin{array}{c}\text { Pike- } \\
\text { perch }\end{array}$ \\
\hline sand & 31.8 & 0 & 0 & 0 & 21.9 & 29.5 & 0 \\
detritus & 47.2 & 0 & 0 & 0 & 11.2 & 15.7 & 0 \\
plant seeds & 3.0 & 0 & 0 & 0 & 1.2 & 0.6 & 0 \\
Chlorophyta & 39.4 & 0 & 0 & 0 & 3.8 & 7.1 & 0 \\
Cladocera & 5.2 & 9.3 & 51.7 & 34.7 & 14.4 & 19.9 & 1.4 \\
Copepoda & 17.0 & 0.9 & 53.2 & 52.7 & 10.6 & 22.1 & 0 \\
Gastropoda & 37.2 & 2.0 & 0 & 0 & 10.5 & 2.6 & 0 \\
Lamellibranchiata & 38.5 & 0.9 & 0 & 2.2 & 44.8 & 9.1 & 0 \\
Chironomidae (larvae) & 64.0 & 56.6 & 88.1 & 94.9 & 57.1 & 70.2 & 4.5 \\
- (Pupae) & 34.8 & 49.6 & 32.0 & 61.8 & 12.2 & 9.9 & 3.1 \\
Oligochaeta & 0 & 10.0 & 25.2 & 20.7 & 11.6 & 18.2 & 0 \\
Cambarus affinis & 0 & 6.7 & 0 & 0 & 0 & 0 & 0 \\
fishes & 0 & 2.1 & 0 & 0 & 0 & 0 & 92.0 \\
other invertebrates*) & 2.9 & 16.1 & 10.7 & 20.0 & 9.2 & 11.3 & 0 \\
\hline
\end{tabular}

*) other invertebrates: Insecta (imago), Hydracarina, Nematoda, Odonata, Hirudinea, Ceratopogonidae, Asellus aquaticus, Coleoptera, Trichoptera, Ostracoda.

roach. In April 1984, however, the food tracts of all pike-perch caught were filled with Chironomidae larvae, and in July with Leptodora kindtii.

In 1982-1983, roach fed mostly on Mollusca (over 60\% of the diet volume) and consumed water plants only during summer (Szczygliniska 1987). In 1984, share of the chronomids increased considerably in roach diet (I-IIIr).

High consumption of the chironomids by benthivorous fishes was coupled with a shirt in the frequency of molluses in the diet of adult bream and roach. Molluscs were more frequent in the intestines of white bream II-IV wb than of bream II- $\mathrm{V} b$. Frequency of Mollusca in white bream and roach dirt was similar (Tab. 3) but white bream selected Lamellibranchia and 2-6 $\mathrm{mm}$ Sphaeridae. Sphaeridae were consumed whole; the fishes did not crush their shells. Relative variations in the diet of the benthivorous fishes was determined by the abundance of the organisms which accompanied Chironomus spp. (Mollusca and Macrophyta in summer, Oligochaeta in spring). Sometimes, the fish diet changed permanently, in accordance with the density of the prey organisms.

Feeding efficiency and fish coexistence

Changes in the fish diets were usually related to the density of prey organisms. Juvenile fishes fed mostly on Copepoda and Cladocera. However, nutritional inter-relations between the plank tivorous fishes were conditioned by variations in the zooplankton 
abundance which, in turn, depended on the hydrological regime of the power plant. The efficiency of deeding on plankton was inversely proportional to the fish size. Hence, juvenile fish were most predisposed to occupy this niche. They affected the size-structure of the zooplankton and forced the adults to change their feeding niches. Lamnes et al. (1985) stated that changes of the feeding niche by the fishes depended on the ratio between zooplankton and chironomids. In -fact, this statement can be developed into a

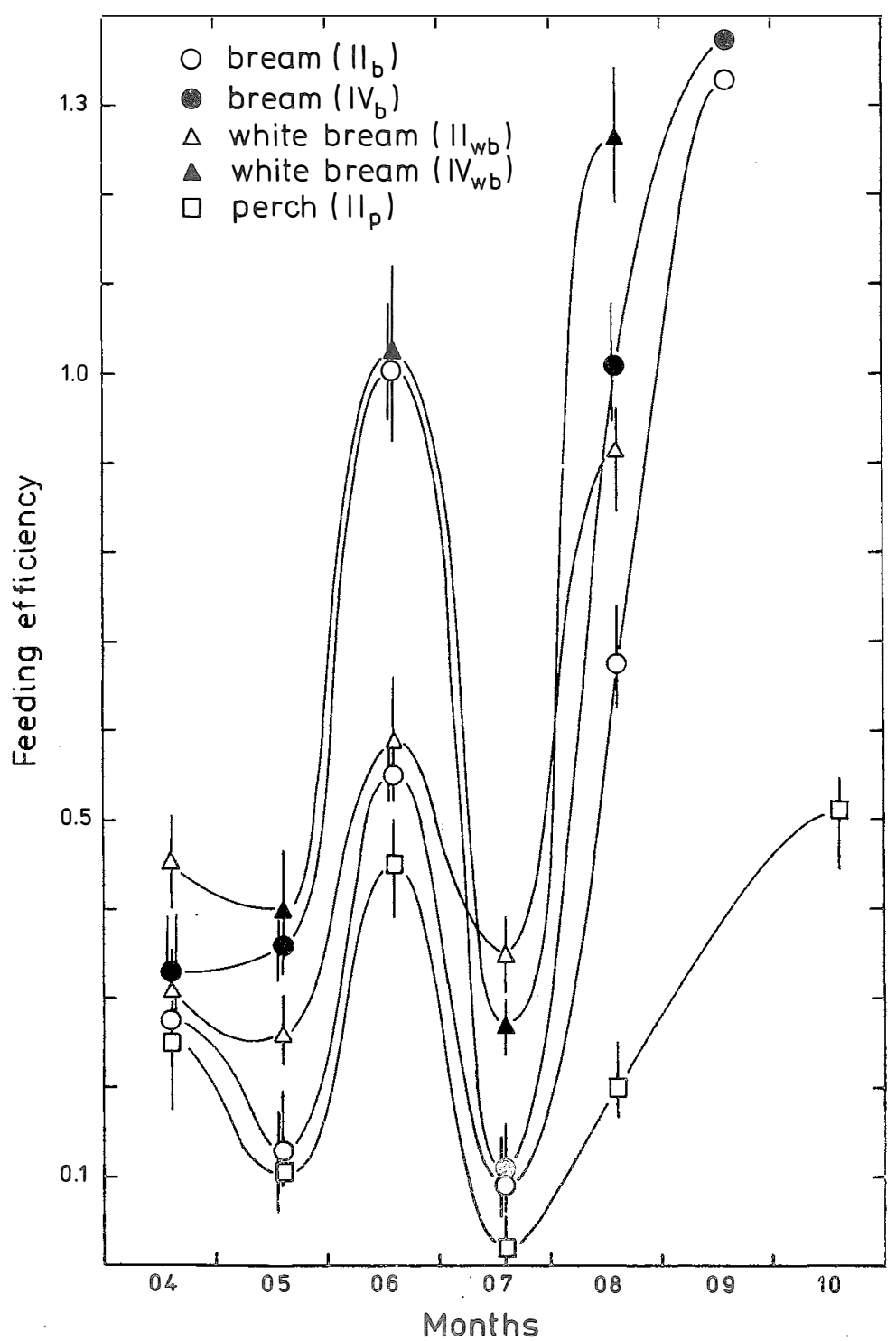

Fig. 2. Feeding efficiency of some bream, white bream and perch cohorts (with SE vertical line) in the phenologic cycle. 
thesis that the niche changes depend on the ratio between the pelagic zooplankton and the soft zoobenthos. Chironomids and Oligochaeta dominated in the intestines of bream, white bream and perch cohorts Ib, Iwb, Ip (in 1984) as well as in the intestines of juvenile ruff and dugeon. Share of these organisms in the fish diet was comparable to their abundance in the environment only when the zooplankton abundance was low. Contrary to this, Cladocera and Cipepoda became importand components of the fish diet (white bream and roach cohorts II-III, bream cohorts I-V, mature bream $25-35 \mathrm{~cm}$ long) only when their resources were abundant.

Ocerall feeding efficiency was higher in white bream than in bream and perch. Efficiency of adult bream and white bream was higher than of the juveniles but when fishes of the same size were compared, white bream appeared to be much more efficient than bream and perch (Fig. 2). Filtrating apparatus of bream is very effective as regards small organisms (Brabrand 1984, Lammens et al. 1985b), much more than of roach, white bream and perch. Due to this, bream is a very plastic species as regards the trophic resources. It consumes more small larvae than white bream as well as larger organisms found in deeper sediment layers. In contradistinction to bream, white bream consumes more medium-sized chironomids (Wielgosz and Tadajewska 1988). Hence, the differences in the microhabitat segregation between bream and white bream were caused by different feeding behaviour of the two species. Bream preferred filtration when food resources were rich in small-sized organisms, while its filtrating ability decreased in case of sediment penetration for large-sized forms. Filtrating apparatus of white bream is less dense so this fish can filtrate its prey even off the sedmiments. Consequently, bream seems to be more selective than white bream, but also less efficient than perch and roach. Roach fed mostly on molluscs and chironomid larvae, and perch supplied its diet with Oligochaeta and Cambarus affinis. Size of the prey organisms and their abundance in the diet of ruff and gudgeon were almost similar. However, when large specimens of Glyptotendipes gripekoveni and Chironomus spp. predominated, ruff seemed to be more efficient than gudgeon (Fig. 3). In these cases, gudgeon fed mostly on the pelagic zooplankton. In autumn, the differences as to the feeding efficiency of ruff and gudgeon dependedn on the abundance of Chironomus spp. and Critopus spp. larvae (1st and 2nd instars), their size, and niche partitioning.

In most cases, however, gudgeon was more efficient than ruff, this being due to its higher selectivity. This species consumed phytophilic Cricotopus spp. mostly, whereas ruff fed more on pelophilic larvae of Chironomus. Feeding efficiency of the fishes depended on prey abundance in the environment and on prey size. It also seems that distribution of the resources may stimulate the feeding strategy and the feeding intensity of the fishes. When the food resources were distributed more or less evently, share of the food components in the fish diet resembles their abundance in the environment. This quite understable considering that total consumption is related to the prey availability and not to the feeding selectivity (Durbin and Durbin 1975). Uneveri distribution of the prey organisms may increase the apetite, especially of predators feeding ad libitum. 


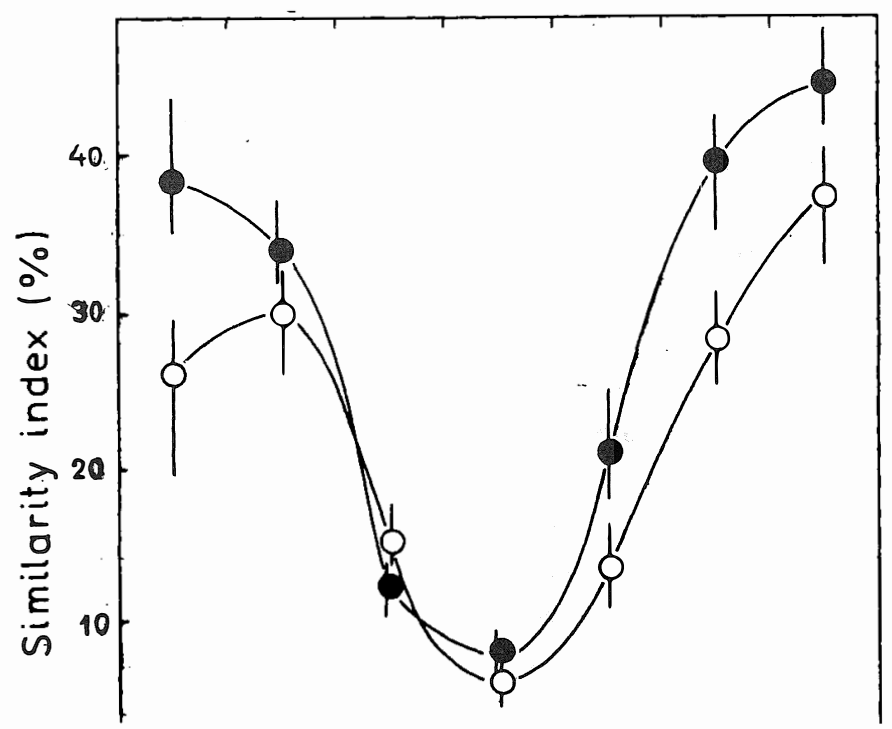

Fif. 3. Feeding efficiency of ruff (light points) and gudgeon (dark points) with CL in the phenologic cycle in 1984.

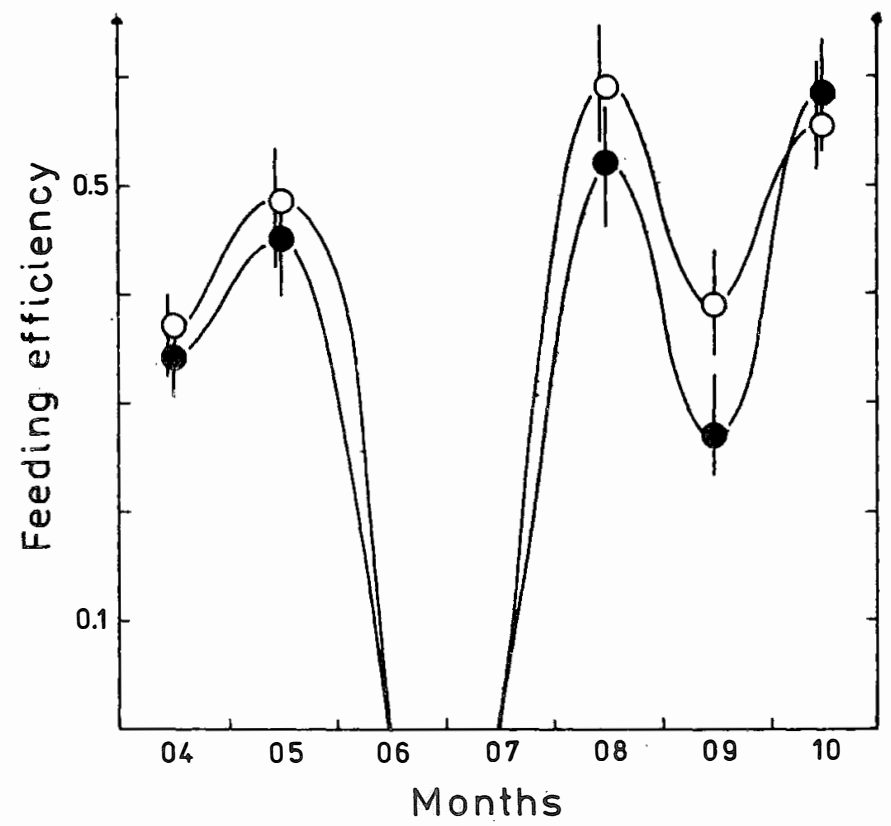

Fig. 4. Index of the food convergence of the fishes (with SE) in 1982 (light points) and 1984 (dark points) in Włock awek Reservoir. Maximal SE of the cohorts in the interspecific relations. 
In many cases abundance of the chironomids in the environment was different than their share in the fish diet. It is possible that the benthivorous fishes consumed different percentage of the chironomid production in different periods. Poddubny and Balanov (1980) suggested that about $80 \%$ of the zoobenthos production were available for the fishes. Lammens (1982) and De nie (1982) are of the opinion that total production of Chironomidae in Lake Tjenkemeer is consumed by bream and eel. Zheltenkova and Kogan (1985) estimated that about 55-80\% of the betnhos production could be used by the benthivorous fishes. In spring, all fishes in the reservoir were highly elective towards Chironomus spp. larvae (Tab. 4). The electiveness index differed for various fish species but tended to increase with fish size. Bream and white bream cohorts I and II as well as juvenile ruff and gudgeon showed negative electiveness, while selectivity of older fishes decreased proportionally to the deficit of Chironomus spp. in the environment. Adult ruff and gudgeon were more selective in spring than in autumn, and the selectivity was relatively more significant for II rf than for II gd. Hence, actual benthic resources of Włocławek Reservoir were determined by the intensity of utilizing their production by the fishes.

Food convergence of the benthivorous fishes differed between autumn and spring, and was higher in 1984 than 1982 (Fig. 4). Most pronounced differences as to the food niches (reflected in different diet composition) were observed in summer. Lack of the available

Table 4

Electivity index of some fish and their cohorts in relation to Chironomus sp. larvae in 1984

\begin{tabular}{|c|c|c|c|c|c|c|}
\hline \multirow{2}{*}{ Species } & \multirow{2}{*}{ Cohort } & \multirow{2}{*}{$\begin{array}{l}\text { Body length } \\
(\mathrm{Lc}-\mathrm{cm})\end{array}$} & \multicolumn{4}{|c|}{ Month } \\
\hline & & & V & VII & VIII & $\mathrm{X}$ \\
\hline \multirow[t]{5}{*}{ bream } & $I_{b}$ & $10.0-15.0$ & 0.69 & -0.63 & -0.42 & - \\
\hline & $\mathrm{II}_{\mathrm{b}}$ & $15.1-20.0$ & 0.57 & -0.41 & 0.24 & - \\
\hline & $\mathrm{III}_{\mathrm{b}}$ & $20.1-25.0$ & 0.77 & 0.43 & 0.25 & - \\
\hline & $\mathrm{IV}_{\mathrm{b}}$ & $25.1-30.0$ & 0.99 & 0.71 & 0.32 & - \\
\hline & $\mathrm{V}_{\mathrm{b}}$ & 30.1 & 0.99 & 0.65 & 0.06 & - \\
\hline \multirow[t]{2}{*}{ white bream } & $I_{w b}$ & $10.0-15.0$ & - & -0.44 & 0.19 & - \\
\hline & II $_{w b}$ & $15.1-20.0$ & 0.79 & -0.26 & 0.24 & - \\
\hline \multirow[t]{2}{*}{ ruff } & $I_{r f}$ & 5.0 & 0.93 & - & -0.28 & 0.51 \\
\hline & $\mathrm{II}_{\mathrm{rf}}$ & 5.0 & 0.97 & - & 0.20 & 0.68 \\
\hline \multirow[t]{2}{*}{ gudgeen } & $I_{g d}$ & 5.0 & 0.84 & - & -0.43 & -0.23 \\
\hline & II $_{\mathrm{gd}}$ & 5.0 & 0.95 & - & 0.21 & 0.51 \\
\hline perch & I - III & $10.0-25.0$ & 0.68 & -0.76 & -0.96 & 0.71 \\
\hline
\end{tabular}


resources in this period resulted in the fact that even the allopatric species showed different feeding habits. It was stated that the food convergence depended totally on the availability and resource partitioning. This was reflected in the size-structure of the prey organisms consumed, dependence of the feeding efficiency on the season, fish species and fish size as well as in the effeciency indices and mehanisms of grazing. The same was found as regards the consumption by predators in relation to the distribution of prey-fish. Pike-perch consumed ruff and gudgeon most of all, and share of these two prey organism in the diet increased proportionally to their density in the habitat (Fig. 5). It was found that bleak was most abundant in the reservoir, but this fish occupied the surface, lenitic water layer and was unavailable for pike-perch which penetrated the deep pelagial. Hence, distribution of the potential prey determined the diet of predators. Due to this.

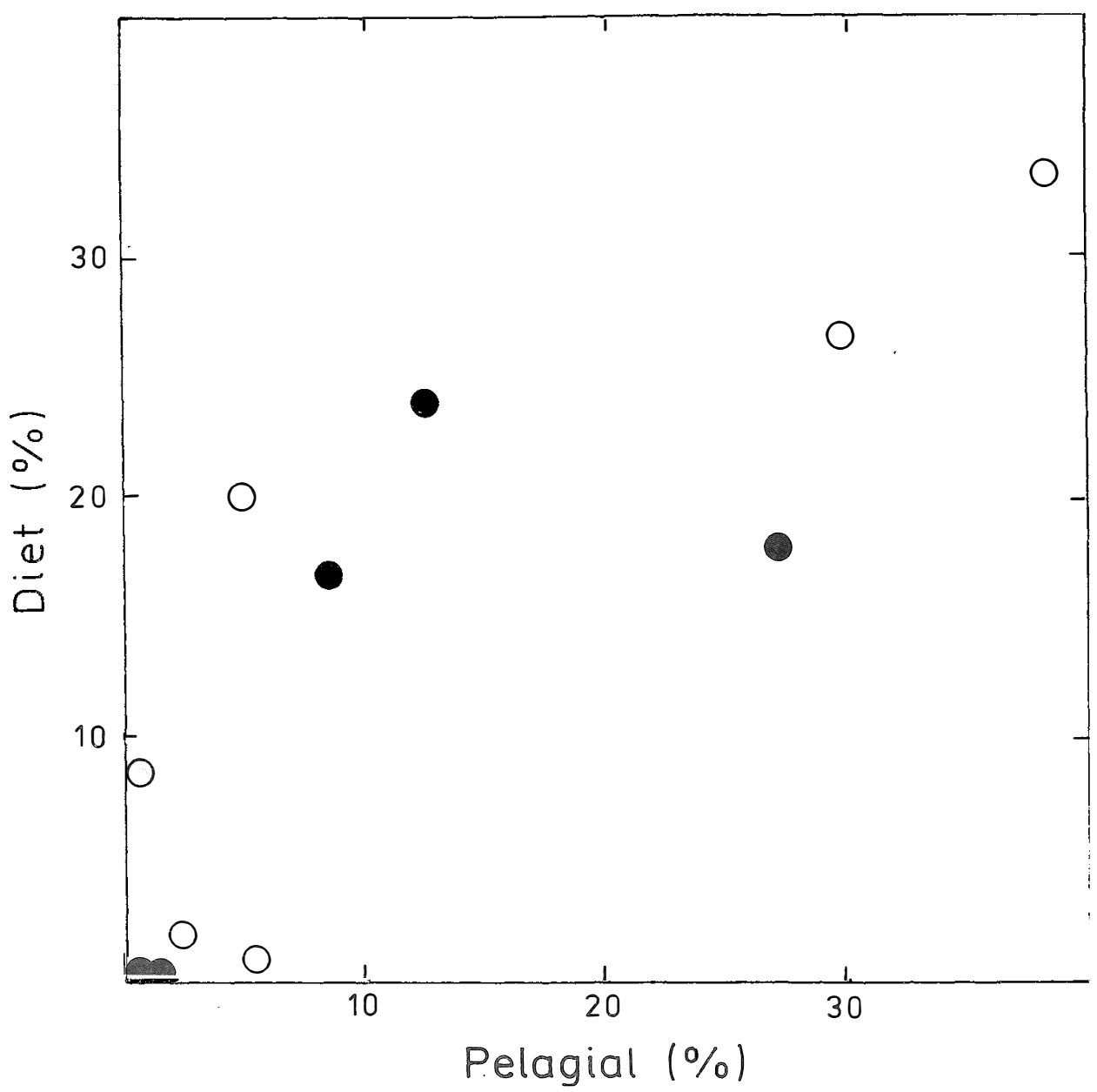

Fig. 5. Corelation between ruff (dark points) and gudgeon (dark points) share in the fish stock and pike-perch diet in 1984 . 
pike-perch reduced the stocks of ruff and gudgeon, i.e. of the weed fishes of no econimic significance. On the other hand, competition appeared to be the basic condition for the coexistence of the benthivorous fishes in the reservoir. Werner and Hall (1979), Schoener (1983), Perison et al. (1985) and Diamond (1978) also stated that interspecific competition was responsible for fish abundance, the latter being adapted to the prey availability. According to Lammens et al. (1985b), fish stock structure is determined by the feeding competition. In addition to this, predatory fishes may induce stock destructuralization and an increase of large-sized specimens in the prey population.

However, it seems that the latter phenomenon may take place only in cases of very limited resources, when competition for food becomes high. In case of abundant resources, only the individual growth is affected, so that disproportions occur in the social structure of the population. Moreover, intraspecies competition is then more important. This is due to the fact that the allopatric species differ as regards the feeding strategy and possibility of utilizing the food resources.

Consequently, even when the same resources are used, the fishes penetrate different microniches and consume organisms of different size (Wielgosz and Tadajewska 1988, Brabrand 1984). As regards the intraspecific interactions, fish coexistance may lead to drastic niche partitioning but also to more diversified diet composition and spreading of the fish species to those habitats that would not be used otherwise.

\section{Condition and growth of the benthivorous fishes}

Similar diet compasition and food convergence reflect the coexistence between the fishes. On the other hand, trends of growth and condition (Fig. 5,6) result from trophic inter-relations.

No interspecies differences were observed as regards fish condition in the size-classes and particular years. This confirms earlier suggestion on high fertility of Whoclawek Reservoir. Its food resources are fairly stable and partitioned between the fish populations with no greater conflicta. In case of adult fishes, average Fulton's index was high for white bream (2.60), followed by roach (2.47), bream (2.35) and perch (2.04). Interspecific differences in the fish condition were of morphologic and individual nature, both as regards the allopatric and the sympatric species. Comparison of the fishes in the same size-classes revealed that white bream was characterized by better condition thare perch and bream. Maximal differences between white bream and perch were noted for juvenile fishes Student's test $t=4.229, p-$ probability $p=0.001$ ), wheares the most pronouneed differences between white bream and bream were observed for cohort III ( $t=$ $4.560, p=0.001)$. Fulton's index for roach cohort $\mathbb{I I}$ was higher than for perch $(t=2.125, p=0.045)$, and condition of roach cohort III differed from that of the same cohort of bream $(t=2.721, p=0.011)$ and perch $(t=2.606, p=0.016)$. There were no significant differences as to the condition of white bream and roach (all cohorts) and of mature bream and white bream (of individual length over $25.1 \mathrm{~cm}$ ). Condition of gudgeon was lower than of ruff $(t=2.940, p=0.018)$ and of older white bream and bream $(p=0.001)$, older roach $(p=0.003)$ and older perch $(p=0.021)$. 


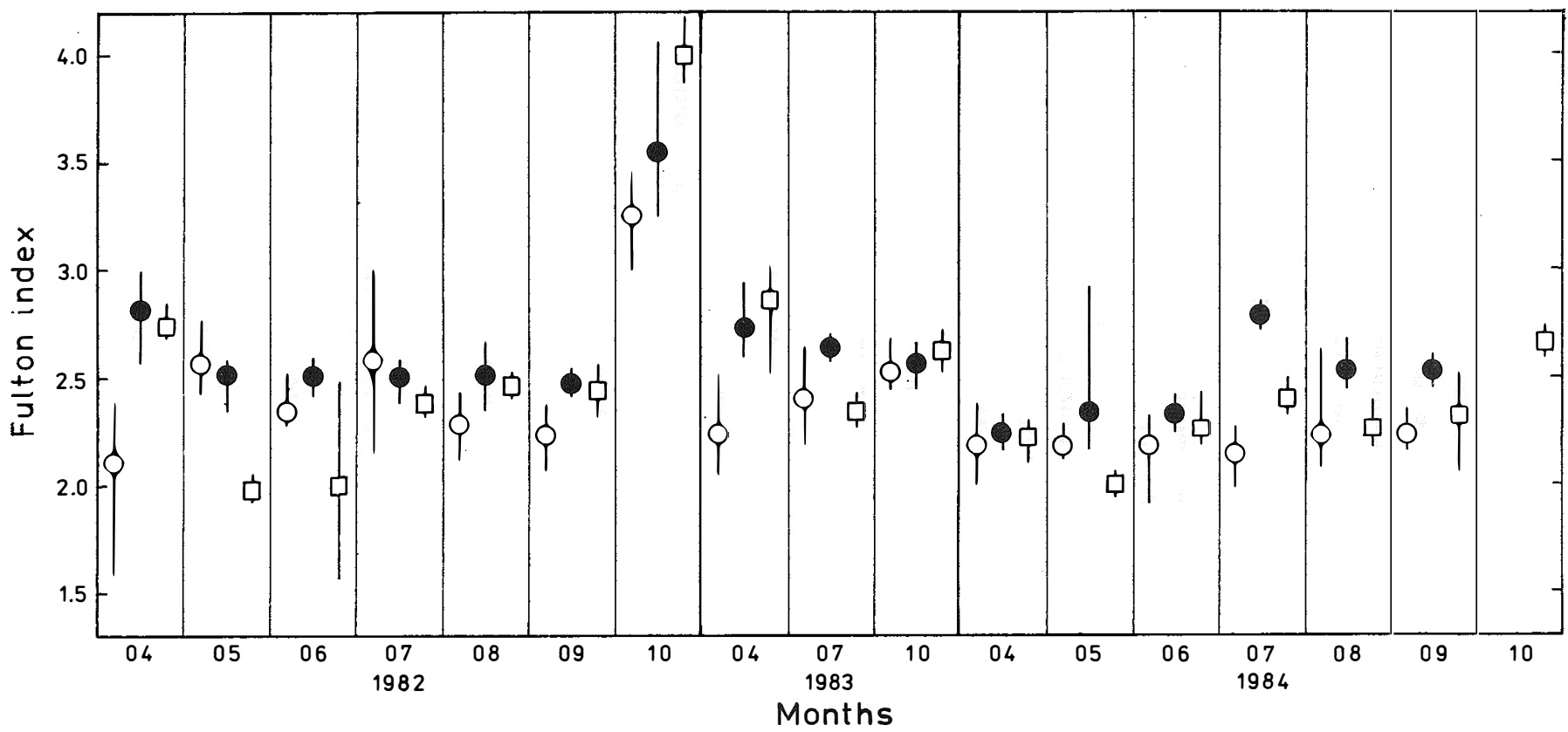

Fig. 6. Average condition of bream (light points), white bream (dark points) and roach (squares) with SE in $1982-1984$. 


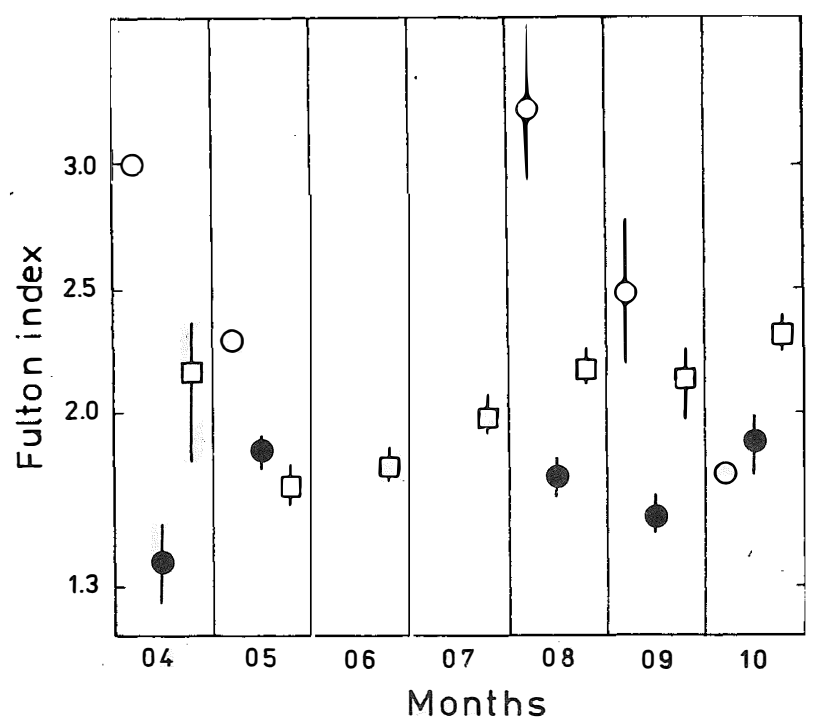

Fig. 7. Average condition or perch (squares), ruff (light points) and gudgeon (dark points) with SE in 1984.

Cazemier (1075, cit. after Lammens 1982) stated that bream growth depended on the standing stock of the chironomids. Bream attained $1 \mathrm{~kg}$ (individual weight) at the age of 9 years when the chironomid biomas exceeded $20 \mathrm{~g}$ f.wt.m ${ }^{-2}$. In Wlockawek Reservoir bream of this age weighed about $980 \mathrm{~g}$ though the chironomid biomas was mower by some 23-37\%. This that was covered by Oligochaeta. Nabiałek (in prep.) found that growth of the growth rate decreased with fish age. Growth of older fishes in Włocławek Reservoir was much better than in most eutrophic lakes (Marciak 1974), Bakanov and Strizhnikova 1979) and other dam reservoirs (Klimczyk-Janikowska 1974, Dorozhkina 1972).

\section{Trophic food webs of the fishes}

Scheme of the trophic webs presented in Fig. 8 deals with abundant species only, i.e. those affecting functioning of the ecosystem. No attention has been given to the fartors stabilizing the trophic relations not to the fish succession. Intensity of grazing by the species using the resources of the same niche can be used as a general measure of the trends in the interspecific relations. Stability of this simple model depends on the resource abundance, resource variability in time, and abundance of the juvenile fishes.

Abundance and structure of the resources as. well as fish fry mortality in the reservoir were affected by the hydrological conditions, especially by the flow rate and variations of the water level. Exposure of the spawning grounds, siltation etc. determined the effictiveness of fish reproduction and fry survival. These, in tum, affected the interspecifie relations (Kazanski 1979). As results from the conditions of fish coexistence (see the feeding efficiency), variations in the abundance of fish fry and juveniles 


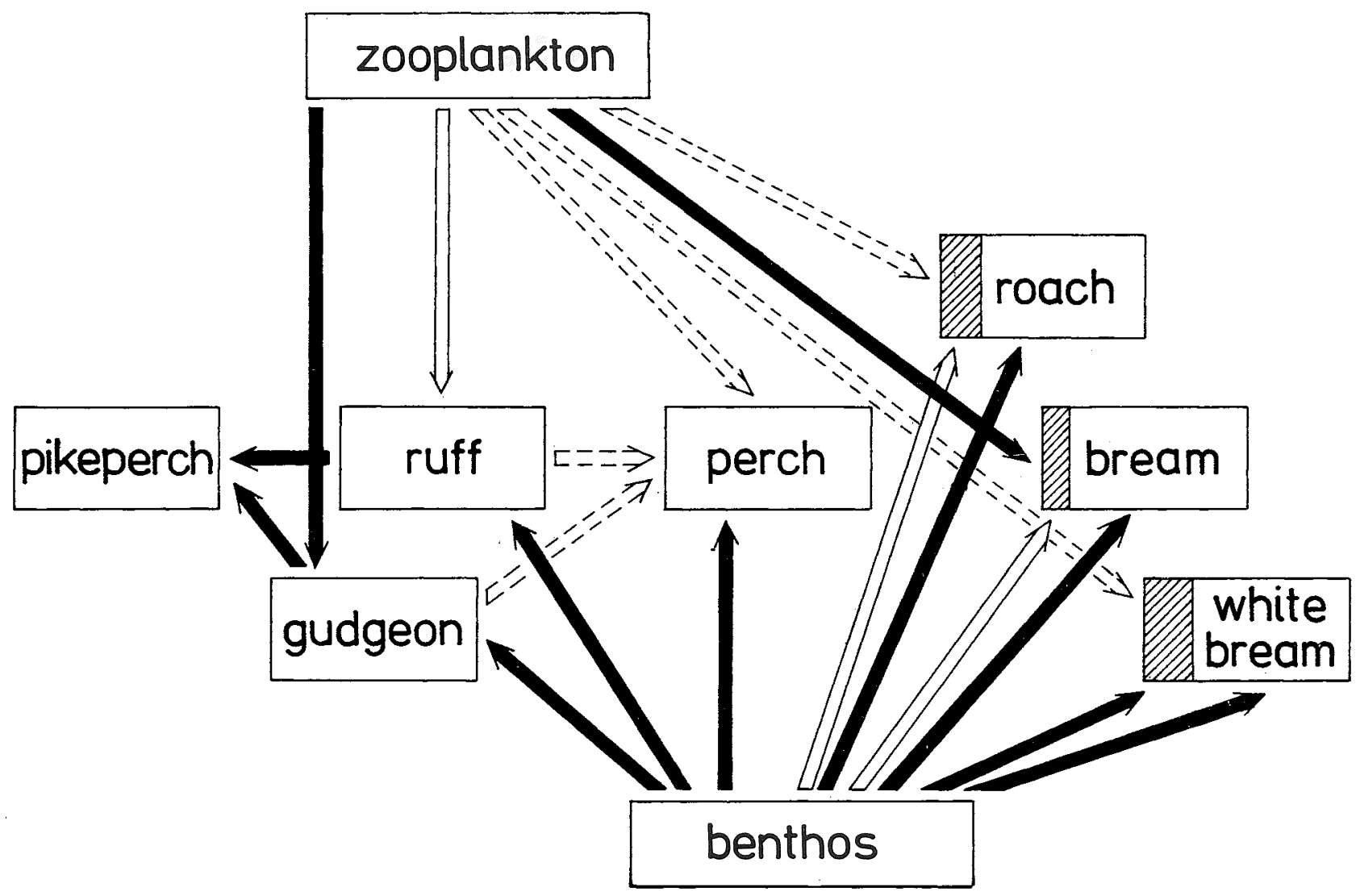

Fig. 8. Scheme of the trophic web of the fishes in Włocławek Reservoir based on the diet components. Division within a bex species reflects share of the juvenile generation (stripped field) and adult fish (light field) in the population size-structure. The pointers represent interspecific evaluation of the inten sity of fish feeding in the same size-classes and of the same feeding behaviour. Black pointers (intensity 15\%) mark a general trend of the interdependence. Light pointers show consumption intensity of $5-10 \%$, broken pointers $(5 \%)$ indicate temporary important direction in the niche shirts. 
depended on the zooplankton abundance. Zhakov and Menshutkin (1974) found that juvenile fishes represented $9-25 \%$ of the fish stock in lakes with high production of the zoobenthos. It seems that the feeding efficiency on the zoobenthos is incersely proportional to the fish size. Hence, competition between planktivorous fishes decreased with fish age due to the fact that older specimens fed on benthic organisms.

Pike-perch, which grazed on ruff and gudgeon, improved edaphic conditions for the development of more valuable species.

\section{ACKNOWLEDGEMENTS}

My thanks are due to the scientific team of the Inland Fisheries Institute (under the leadership of doc. dr. hab. Roman Sych) for their collaboration and supplying me with the dishes caught in 1982, 1983. I would like to thank prof. Maria Brylińska for her kind supervision of my work. I am also indebted to dr Anna Szczyglińska, dr Bożena Kuklińska, Mr Sławomir Boroń and dr Janusz Terlecki for making available the data needed in estimating the feeding efficiency and condition of some fishes.

The studies have been financed by the Institute of Ecology of the Polish Academy of Sciences.

\section{REFERENCES}

Abel-Malek S.A., 1980: Pitaniye i pishchevye vzaimootnosheniya ryb ozera Karun (ARE). - Vopr. Ikht. 20: 272-276.

Anderson G., Berggren H., Cronberg G., Gelin C., 1978: Effect of planktivorous and benthivorous fish on organisms and water chemistry in eutrophic lakes. - Hydrobiologia, 59: 9-15.

Bakanov A.I., Strizhnikova L.N., 1979: O svazi mezhdu izmenenyami bazy i pitanem leshcha $\mathrm{Abramis}$ brama orientalis Berg $\mathrm{v}$ Volzhskom plese Rybinskogo vodokhranilischa. - Vopr. Ikht. 19: $134-141$.

Boroń Sł., Kuklińska B., 1987: Food of ruffe (Gymnocephalus cernuus L.) and gudgeon (Gobio gobio L.) in Włocławek dam reservoir. - Acta Icht. et Piscat. XVII, 1:59-76 (in Polish).

Brabrand A., 1984: Microhabitat segregation between bream (Abramis brama L.) and white bream (Blicca björkna $\quad$ L.) In a mesotropic lake, SE Norway.- Pol. Arch. Hydrobiol. 32: 99-108 (in Polish).

Ciunelis A., 1985: Fauna denna zbiornika włosławskiego. [Bottom faunae of Włocławek dam reservoir]. UMK Torun (in manuscript).

Crowder L.B., Cooper W.E., 1982: Habitat structural complexity and interaction between blue - gills and their prey. - Ecology, 63: 1802-1813.

Diamond J.R., 1978: Niche shifts and the rediscovery of interspecific competition. - Am. Sci. 66: $322-331$.

Dorozhkina T.Y., 1972: Morfologicheskaya kharakteristika gustery Blicca björkna L. oz. Ilmen. Vopr. Ikht. 12: 184-192.

Durbin A.G., Durbin E.G., 1975: Grazing rates of particle size and concentration. - Mar. Biol. 33: $265-277$. 
Gizińska A., Błędzki L.A., Kentzer A., Rejmanowska K., Szempliński K., Wiśniewski R., Żytkiewicz R., 1985: Chydrobiologiczna charakterystyka zbiornika włocławskiego.1[ Hydrobiological characteristic of Włocławek dam reservoir] UMK Toruń (in manuscript).

Gižyński Z., 1983: Fauna denna zbiornika włocławskiego 1982. [Bottom faunae of Włocławek dam reservoir 1982]. - UMK Toruń (in manuscript).

Grudniewski C., 1985: Synteza wyników badań na temat ilościowego szacunku populacji ryb nieeksploatowanych gospodarczo we włocławskim zbiomiku zaporowym. [Summary of surveys on the quantitative estimation of economically unexploited fish population, in Włocławek dam reservoir]. ART Olsztyn (in manuscript).

Ivlev V.S., 1955: Eksperimentalnaya ekologia pitaniya ryb. - Pishchpromizdat., Moskva.

Kazanskiy A.B., 1979: Model troficheskoy seti ikhtiocena Cymlianskogo vodokhranilishcha. - Vopr. Ikht. 19: 482-488.

Klimczyk-Janikowski M., 1974: Food and biometric characteristic of the silver bream (Blicca björkna) L.) from the reservoir at Gochałkowice. - Acta Hydrobiolog. 16! 241-254 (in Polish).

Lammens E.H.R.R., 1982: Growth, condition and gonad development of bream (Abramis brama L.) in relation to its feeding conditions in Tjeukemeer. - Hydrobilogia, 95: 311-320.

Lammens E.H.R.R., 1984: A comparison between the feeding of white bream (Blicca björkna) and bream (Abramis brama). - Verh. Internat. Verein. Limnol. 22: 886-890.

Lammens E.H.R.R., de Nie H.W., Vijverberg J., van Densen W.L.T., 1985a: Resource partitioning and niche shifts of bream (Abramis brama) and eel (Anguilla anguilla) mediated by predation of smelt (Osmerus eperlanus) on Daphnia hyalina. - Can. J. Fish. Aqatic Sci. 42: 1342-1351.

Larnmens E.H.R.R., Geursen J., McGillavry P.J., 1985 b: Diet shifts, feeding efficiency and coexistence of bream (Abramis brama), roach (Rutilaus rutilus) and white bream (Blicca björkna) in eutrophicated lakes. - Proc. V congr. Europ. Ichthyol, Stockholm, 18pp.

Laughlin D.R., Werner, E.E., 1980: Resource partitioning in two coexisting sunfish: pumpkinseed (Lepomis gibbosus) and northern longear sunfish (Lepomis megalotis peltastes). - Can. J. Fish. Aquat. Sci. 37: 1411-1420.

Lynch M., 1979) Predation, competition and zzoplankton comunity structure: an experimental study. - Limnol. Oceanogr. 24: 253-272.

Mittelbach G.G., 1984: Predation and resource partitioning in two sunfishes (Centrarchidae). Ecology, 65: 499-514.

Nie H.W. de, 1982: A note on the significance of larger bivalve molluscs (Anodonta spp. and Dreissena sp.) in the food of the eel (Anguilla anguilla) in tjeukemeer. - Hydrobiologia, 95: 307-310.

Perison G., Cryer M., Winfield I.J., Townsend C.R., 1985: The impact of reduced nutrient loading on the fish community of a smoll isolated lake, Alderfen Broad. - Proc. 4 th Brit. Freshw. Fish. Conf., Univ. Liverpool, 8pp.

Poddubny A.G., Kabanov A.I., 1980: O kolichestvennoy ocenke vyedaniya bentosu rybami. - Vopr. Ikht. 20: 888-896.

Ricker W.E., 1975: Computation and interaction of biological statistics of fish populations. - Bull. Fish. Res. Bd. Can. 191: 382p.

Schoener T.W., 1983: Field experiments on interspecific competition. - Am. Nat. 122: 240-285.

Sjorygin A.A., 1939: Pitaniye, izbiratelnaya spsobnost i piskchevye vzämooznosheniya nekotorych Gobid ae Kaspiy skogo Mora. - Zool. Zh. 18: 27-53.

Stolarov I.A., 1985: Pitaniye i pishchevye vzaimootnosheniya sazana Cyprinus carpio L., leshcha Abramis brama orientalis Berg i vobly Rutilus rutilus caspius (Jak.) v Kizlarskom zalive severnogo Kaspiya. - Vopr. Ikht. 25: 443-451.

Szczygliníska A., 1987: Diet composition daily feeding paterns of roach (Rutilus rutilus (L.)) in Włocławek dam reservoir in 1982-1984. - Acta Icht. et Piscat. XVII, 2: 55-68.

Terlecki J., 1987: The diet of adult perch (Perca fluviatilis) in the Vistula dam reservoir in Włocławek. - Acta Ichth. et Piscat. XVII, 1: 43-57. 
Vijverberg J., van Densen W.L.T., 1984: The role of fish in the foodweb of Tjueremeer. - Verh. Internat. Verein. Limnol 22: 891-896.

Werner E.E., Hall D.J., 1979) Foraging effeciency and habitat switching in competing sunfishes. Ecology, 60: 256-264.

Wielgosz S., Tadajewska M.,1988:Factors determining diet composition and food availability for bream. Abramis brama (L.) and white bream, Blicca björkn (L.) in Włocławek dam reservoir. - Acta Ichth. et Piscat. XVIII,1: 79-100.

Zhakov L.A., Menskutkin W.W., 1974: Matematicheskaya model ozernogo ikhtiocenoza - Vopr. Ikht. 14: 387-395.

Zheltenskova M.W., Kogan A.W., 1985: Ob izucheni ispolzovaniya rybami kormovoy bazy. - Vopr. Ikht. 25: 256-263.

Translated:

Dr. M. Bnińska

\section{Sławomir Wielgosz}

\section{CZYNNIKI OKRES̊LAJĄCE WSPÓÆBYTOWANIE I ZALEŻNOŚCI TROFICZNE W ICHTIOCENOZIE ZBIORNIKA ZAPOROWEGO WE WEOCEAWKU}

\section{STRESZCZENIE}

Praca syntetyzuje zachowanie się i koegzystencję głównych gatunków ichtiofauny zbiornika: leszcza, krąpia, płoci, sandacza, okonia, jazgarza i kiêłbia. Potencjał zasobów zooplanktonu pelagicznego determinowany był reżimem hydrologicznym elektrowni i rósł $z$ retencją wody. O stabilności i zasobności środowisk dna decydowała zmienność przepływu wymuszająca procesy resuspensij, przemieszczania $i$ resedymentacji osadów. Wysoka biomasa zoobentosu oraz dominacja form dużych sprzyjała efektywnemu wykorzystaniu potencjału zasobów. Dysproporcje struktur diet dotyczyły gatunków i wielkości ryb i spowodowane były dostępnością ofiar w badanych cyklach fenologicznycn i latach. Młodzież ryb generalnie nażera się różnej wielkości frakcjami Copepoda i Cladocere oraz chironomidami i oligochetami. Proporcje ich udziału'w pokarmie, ukierunkowane stosunkiem zooplanktonu do zoobentosu mię kkiego, stosowane były do zasobności środowiska. Starsi bentosożercy konsumowali bentos $\mathrm{w}$ różnym stopniu uzupełniając dietę zooplanktonu i roślinami. Sandacz będący obligatoryjnym rybożercą wywierał presję na jazgarza i kiełbia. Analizą składu ofiar i frakcji ich wielkości w pokarmie, były w zależności efektywności żerowania od sezonu, gatunku i rozmiarów bentosożerców oraz wsłaźnikami selektywności i mechanizmem pozyskiwania łupu uzasadnione, co wskazuje pokrywanie się spektrów diet jest funkcją dostępności i podziału zasobów. Wskkazując na różną strategię zdobywania łupu przez gatunki allopatryczne stwierdzono, ze podstawowym warunkiem koegzystencji bentosożerców w' zbiorniku jest konkurencja. Miarą współzależności troficznych jest dobra kondycja i ponadprzeciętny wzrost ryb. Fakt ten potwierdzał żyzność ekosystemu, zagęszczenie i stabilność zasobów środowiska oraz względnie bezkonfliktowy ich podział między populacje ryb.

Author's address:

Received: 89.11.21

Dr Sławomir Wielgosz

Katedra Zoologii

Akademia Rolniczo-Techniczna

10-957 Olsztyn, Polska (Poland) 